\title{
The Cyclops Mountains Massif (New Guinea, Indonesia) as the provenance area for metal-bearing shelf sediments from the Carolinian Sea
}

\author{
Karol ZGLINICKI ${ }^{1, *}$ and Krzysztof SZAMAŁEK ${ }^{1}$ \\ 1 Polish Geological Institute - National Research Institute, Rakowiecka 4, 00-975 Warszawa, Poland
}

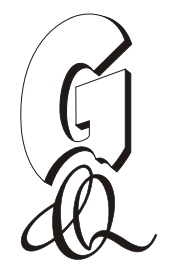

Zglinicki, K., Szamałek, K., 2020. The Cyclops Mountains Massif (New Guinea, Indonesia) as the provenance area for metal-bearing shelf sediments from the Carolinian Sea. Geological Quarterly, 64 (2): 480-491, doi: 10.7306/gq.1512

Associate Editor: Stanisław Wołkowicz

\begin{abstract}
In 2009, on the initiative of PT Halmahera Perkasa the "Jayapura" exploration project was carried out in Indonesia. As part of this project, exploration of the sea bottom in the northern coast of New Guinea was carried out over a distance of $\sim 45 \mathrm{~km}$. The suction dredge collected 59 samples of loose sediments from the shelf bottom surface of the Carolinian Sea (to a depth of $60 \mathrm{~m}$ below the sea-floor). The extracted samples are usually poorly and moderately sorted sands (5 samples), medium-grained sands (21 samples), and fine-grained sands (33 samples). The sand composition shows, among others, a wide spectrum of heavy minerals of ultra-mafic (Cr-garnet, chromium spinel, Mg-olivine) and metamorphic (epidote, clinochlore, amphibole, titanite) origin. The content of heavy minerals in the sediments is up to $54.77 \mathrm{wt} \%$. It was found that the source of heavy fraction in the eastern and western parts of the coast is the rock of the ophiolite series building the Cyclops Mountains Massif. The mineral composition of sediments from the central coastal zone corresponds to the types of rocks building the metamorphic core of the Cyclops Mountains (amphibolite, gneisses, andesite). Three mineral-geochemical subprovinces were determined on the basis of analyses of heavy mineral decomposition and chemical analyses of sediments. Shelf sediment from the eastern part of the coast is characterized by an increased content of strategic metals (Ni up to 3560 , W up to 3130 and Co up to $142 \mathrm{ppm}$ ). In the central zone, the $V$ content increases up to $244 \mathrm{ppm}$ and the Ag content up to $5 \mathrm{ppm}$. In the shelf sediments there is a strong depletion in the REE.
\end{abstract}

Key words: continental shelf sediments, Cyclops Mountains, New Guinea, heavy minerals, geological prospection, marine minerals.

\section{INTRODUCTION}

Mineral composition of coastal sediments is the result of provenance rock-type and sedimentation cycle factors (Morton and Smale, 1990; Morton and Hallsworth, 1994, 1999; Garzanti and Andò, 2007). Sedimentation processes can lead to concentration of metal-bearing sediments, which may be defined as economically significant in the whole spectrum of texture: gravel, sand, mud, silt and clay deposited offshore (Van Gosen et al., 2014). Mineral composition of the (inner) shelf sediment is closely linked to coastal hydrodynamics, where there is a direct interaction between the marine and littoral environments (Rosa et al., 2013).

Intense weathering processes under tropical conditions combined with a constant uplift of the area can contribute to the supply of large volume of sediments of different geochemical compositions to nearby water reservoirs (Liu et al., 2012). The

\footnotetext{
* Corresponding author, e-mail: zglinicki.karol@pgi.gov.pl
}

Received: August 1, 2019; accepted: October 22, 2019; first published online: February 21, 2020 rivers of New Guinea transport $1.7 \times 10^{9} \mathrm{t}^{-1}$ of sediments to the World Ocean yearly (Milliman, 1995). The amount of mineral masses coming in is spatially distributed within the whole inner shelf surrounding the island. A significant part of the sediments is supplied by rivers draining the areas of northern New Guinea (Milliman and Syvitski, 1992; Milliman, 1995). The existence of underwater canyons directed towards the edge of the New Guinea Trench cause the direct distribution of sediments on the shelf to disperse. Hypothetically, the hypopycnal or homopycnal flows are particularly significant for the process of moving a large volume of material, but there is no research data from this process. Part of the rock material is accumulated within the shelf and continental slope. The rest of the sediment is moved by gravity or hyperpycnal flows to the open sea mostly by a system of submarine channels (Krause, 1965; Hamilton, 1979; Tregoning and Gorbatov, 2004; Miller and Kuehl, 2009). The quantity and quality of the material supplied to the coastal waters of New Guinea depends on the mass movements (land slumps, landslides) and wave processes having a destructive effect on the coastline.

The northern part of New Guinea (Jayapura region) is now a marginal zone of convergence between the Indo-Australian and Pacific plates. The presence of convergent plate boundaries results in the possibility of occurrence of characteristic deposit 
mineralization similar to that associated with the island arcs, such as podiform chromite (Mosier et al., 2012), Besshi-type copper sulphide deposits (Dergatchev et al., 2011), Kuroko-type massive sulphide (Sato, 1977) and porphyry copper ores (Sun et al., 2017). The complex geological history of the Jayapura area (Monnier et al., 1999), results in the presence of numerous base metals of potential economic significance (Baker, 1955, 1956; Ubaghs, 1955; Pieters et al., 1979 Thirnbeck, 2001, 2004; Zglinicki, 2016). Department of Energy and Mineral Resources West Papua Province (Ind.: Dinas Energi Dan Sumber Daya Mineral Provinsi Papua Barat; Peta..., 1995) has identified five provinces of significant mineral deposits on the island of New Guinea, which include the Jayapura region with a $\mathrm{Cu}-\mathrm{Zn}-\mathrm{Pb}-\mathrm{Fe}-\mathrm{Cr}-\mathrm{Co}-\mathrm{Ni}$ zone, within the Cyclops Mountains Massif. The lithologically diverse formations of the area, resulting from the complex geodynamic genesis, may abound in a number of elements and useful metals (Baker 1955; Ubaghs, 1955; Pieters et al., 1979). Probably, undescribed types of deposits may exist around the Cyclops Mountains Massif as: alluvial $\mathrm{Ag}-\mathrm{Au}, \mathrm{Cr}, \mathrm{Ni}, \mathrm{Co}, \mathrm{PGE}$; coastal Ti, Ni, $\mathrm{Co}, \mathrm{Cr}, \mathrm{Au}, \mathrm{Ag}, \mathrm{PGE}$; and epithermal Au.

The depletion of onshore mineral deposits makes it necessary to conduct continuous research and exploration in marine areas (Szamałek et al., 2013, 2015, 2018). The high geopotential of seas and oceans implies an increase in the deep sea mining role (Kotliński, 2001; Szamałek and Mizerski, 2011). Nowadays, marine geological and mining activity is focused on the coastal and continental shelf areas under the jurisdiction of the Coastal State (UNCLOS, 1982; Szamałek and Mizerski, 2011; Wołkowicz and Paulo, 2019). The quarry mining of loose minerals is an important and easily accessible source of useful metal raw material. The increasing demand for non-energy raw materials, including metals of strategic importance, creates the need to reach for mineral resources of seas and oceans. Considering geological and mining opportunities of ocean resources, many researches are conducted in this region (offshore tin mining - PT Timah TBK, Indonesia; extraction of diamonds - Namibia, De Beers Group, Solwara Project, Bismarck Sea - Nautilus Minerals, PNG).

As part of the geological operations carried out in the Malay Archipelago (Szamałek et al., 2013, 2015), geological reconnaissance of shelf sediments from the Carolinian Sea was done. The aim of the project was to determine the source area, the type of parent rocks and the spatial variability of mineral sediments. The results may be the basis for the continuation of detailed identification of the deposit from the shelf around the coast of New Guinea. Sea sediments of the Jayapura coast are the subject of detailed geological analyses for the first time. The results may be used for reconstruction of the geological evolution of the northern coast and may contribute to a better understanding of the development of the marginal convergence zone of New Guinea and the deposit formation processes.

\section{GEOLOGICAL SETTING}

The northern part of New Guinea has a complex geological history, so far not explained in details (Davies, 2012). The geodynamic evolution of the region has resulted in an isolated coastal massif of the Cyclops Mountains (Fig. 1) and a narrow continental shelf formed in the Melanesian Collision Arc zone (Krause, 1965; Monnier et al., 1999; Cloos et al., 2005). The geological structure of the Carolinian Sea shelf is very poorly known in this region. Krause (1965) suggests that the stratigraphy and history of seabed formation is closely related to the formation of the northern coast of New Guinea.

Geological exploration carried out in the 1950s (Baker, 1955, 1956; Ubaghts, 1955) and earlier by Zwierzycki (1921) in the Cyclops Mountains contributed significantly to the petrographic and mineralogical recognition of the region.

The Cyclops Mountains can be considered an anticline composed of two floors overlapping an unknown ground (Monnier et al., 1999). The anticline core consists of crystalline schists, gneisses and metamorphosed rocks of the calc-alkaline series (Gisolf, 1921; Zwierzycki, 1921; Baker, 1955; Monnier et al., 1999). The metamorphic rocks contain ore minerals, such as chalcopyrite, ilmenite, hematite, magnetite, rutile, and platinum group metals.

The upper floor of the Cyclops Mountains is composed of an ophiolite sequence obducing on a metamorphic core. The structure of the ophiolite complex is typical for ophiolite series. It consists of residual, mantle peridotites, cumulates of isotropic gabbro, massive dolerites, troctolites and small amounts of pillow and boninite lavas (Baker, 1955; Monnier et al., 1999; Pubellier et al., 2004). Peridotites are represented by harzburgites, dunites, wehrlites and websterites. Chromium spinels, pyrrhotite, chalcopyrites, magnetites and platinum group metals (PGM) appear in ultramafic rocks. The mafic ophiolite complex consists of plutonic and volcanic alkaline rocks represented by gabbro, troctolites, dolerites and pillow lava. Unlike plutonic rocks, the mafic series is almost unchanged by serpentinization processes (Baker, 1955; Monnier et al., 1999). Bornite, chalcopyrite, chalcocite, covellite, cubanite, pyrite, pyrrhotite, chromite, hematite, ilmenite, magnetite and native PGEs are found in the ophiolite rocks. The ophiolite sequence is covered in the SE by volcanic rocks of the Auwewa Formation, and by marine sediments of the Hollandia Group on the SE side of this ophiolite sequence. The entire Cyclops Mountains Massif is covered with Quaternary gravel and sand sediments (Monnier et al., 1999). Geochemical studies of the rocks of the Cyclops Mountains Massif carried out by Monnier et al. (1999) indicate that the ophiolite was formed in a supra-subduction environment. The geodynamic evolution of the Cyclops Mountains lasted from the Eocene to Pliocene.

\section{STUDY AREA}

The exploration area included a shallow seabed (Fig. 1) on the northern coast of New Guinea (Jayapura region), $\sim 45$ kilometres long and 6,434 hectares in size (located between $140^{\circ} 20^{\prime} 0 " E-45^{\prime \prime} 0 " E$ meridian and $2^{\circ} 32 " 0 " S-26 " 0 " S$ parallel). In 2009, during the research cruise, 58 samples of loose sediments from 24 points, $\sim 2 \mathrm{~km}$ apart on average, were collected with a suction dredge (Table 1) from the Carolinian Sea shelf bottom. The bottom sediment was excavated from the shelf during summertime, when there was no upwelling on the coast. The cruise route and the sampling points were defined by the exploration concession issued by the Governor of $\mathrm{Pa}$ pua Province for PT Halmahera Perkasa. The sea depth ranged from 18 to 30 metres. The distance from the collecting points to the land ranged from 100 to 460 metres. The weight of the excavated sediment was $\sim 2 \mathrm{~kg} / \mathrm{per}$ sample. The loose material was transferred to specially prepared hoppers on the ship. For analytical purposes, the weight of samples was reduced by quartering to $\sim 70 \mathrm{~g}$. 


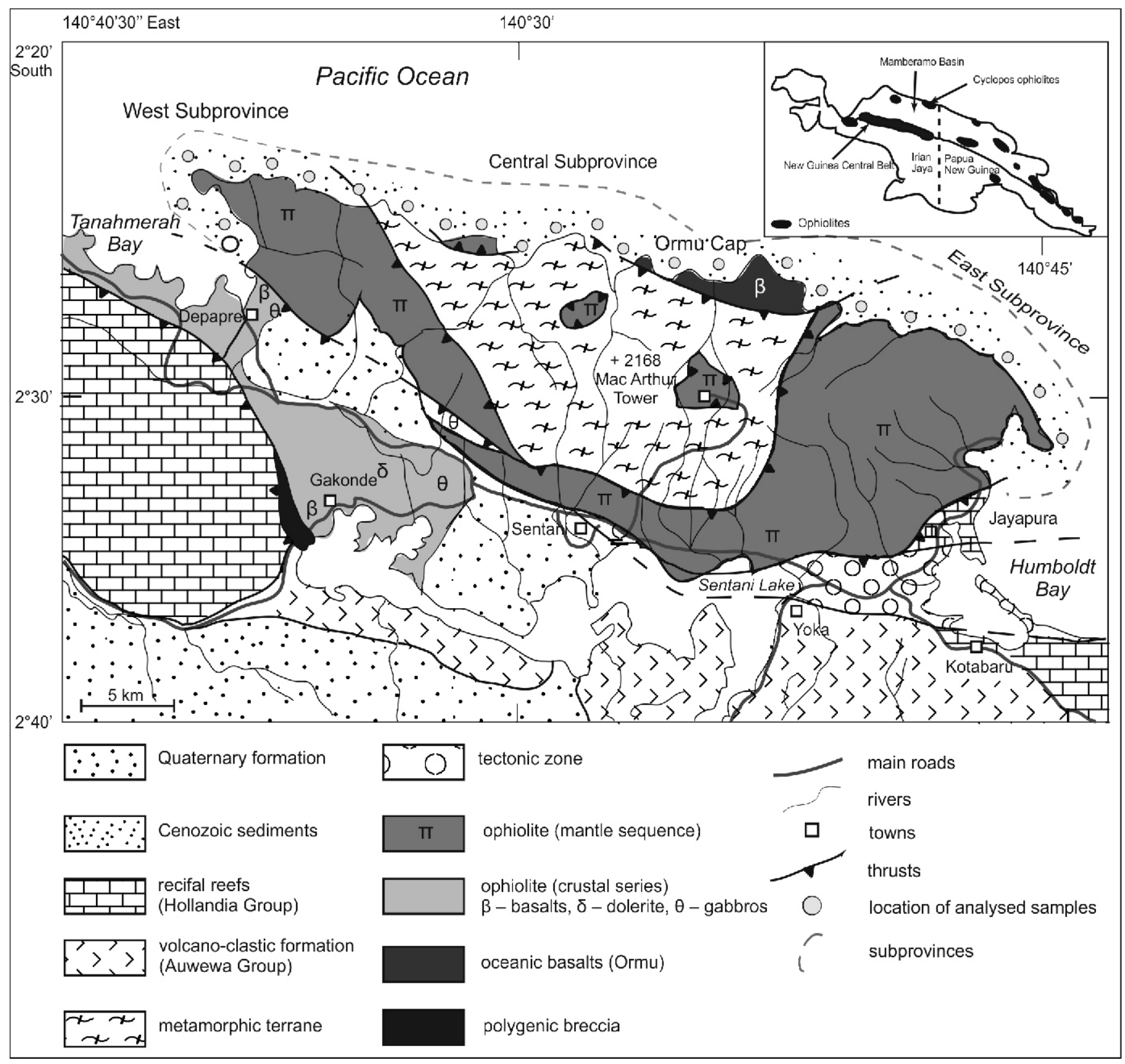

Fig. 1. Geological map of the Cyclops Mountains in Irian Jaya (after Monnier et al., 1999)

\section{MATERIAL AND METHODS}

Shelf sediments were washed with deionized water to purify and remove sodium chloride $(\mathrm{NaCl})$. Using $10 \%$ acetic acid and $30 \%$ hydrogen peroxide, fragments of marine fauna (foraminifers, sponges, bivalves, snails, corals) were dissolved in a water bath at $60^{\circ} \mathrm{C}$. The sieve analysis was performed for the samples of sediment extracted with a suction dredge, after removing organic elements from the samples. The sediment was sieved through a set of nylon sieves with a mesh diameter of 2-0.063 mm according to Wenthworth classification (1922). For statistical calculations, the open source program GRADISTAT v.5.11 (Blott and Pye, 2001) was used. For the separation of heavy fraction from the samples, sodium polytungstate of density $2.89 \pm 0.02 \mathrm{~g} / \mathrm{cm}^{3}$ was used. Heavy minerals were immersed in epoxy resin (Araldite 2020). The phase composition was investigated using an AXS D8 Advance Davinci Bruker diffractometer equipped with a copper anode lamp. Diffractograms were recorded in the angle range $3-85^{\circ}$ $2 \theta$ ( Cu K $\alpha$ ), measurement step $0.02^{\circ}$, and measurement time: $2.5 \mathrm{~s} /$ step. Crystalline phases were identified using X'Pert HighScore Plus software by comparing the registered diffractograms with the ICDD PDF - 2 and PDF - 4+ standards. SEM-BSE microscopic observations were performed with the use of a $\Sigma / G M A V P$ scanning microscope equipped with two EDS detectors (SDD XFlash | 10). The analyses were performed at an accelerating voltage of $25 \mathrm{kV}$ in a high vacuum. Samples for SEM and EPMA tests were covered with coal. Point analyses of chemical composition were performed with the use of a CAMECA SX-100 electron microprobe equipped with wave dispersion spectrometers. The analysis was per- 


\section{Location data of the marine sediment samples}

\begin{tabular}{|c|c|c|c|c|c|}
\hline No. & Sample & Longitude & Latitude & $\begin{array}{l}\text { Water } \\
\text { depth } \\
{[\mathrm{m}]}\end{array}$ & $\begin{array}{c}\text { Distance } \\
\text { from coast } \\
{[\mathrm{m}]}\end{array}$ \\
\hline 1 & NMI 01/25/60 & $140^{\circ} 38^{\prime} 10.4^{\prime \prime E}$ & $2^{\circ} 27^{\prime} 58.2^{\prime \prime S}$ & 22 & 330 \\
\hline 2 & NMI 02/17 & $140^{\circ} 44^{\prime} 36.0^{\prime \prime E}$ & $2^{\circ} 31^{\prime} 30.1 " \mathrm{~S}$ & 25 & 130 \\
\hline 3 & NMI 03/42 & $140^{\circ} 36^{\prime} 55.0^{\prime \prime} \mathrm{E}$ & $2^{\circ} 26^{\prime} 23.9^{\prime \prime S}$ & 24 & 460 \\
\hline 4 & NMI 05/62/63 & $140^{\circ} 44^{\prime} 23.6^{\prime \prime E}$ & $2^{\circ} 30^{\prime} 36.2^{\prime \prime S}$ & 25 & 380 \\
\hline 5 & NMI 06/23 & $140^{\circ} 28^{\prime} 58.6 " \mathrm{E}$ & $2^{\circ} 25^{\prime} 46.3^{\prime \prime S}$ & 22 & 125 \\
\hline 6 & NMI 07/14/64 & $140^{\circ} 40^{\prime} 48.1 " \mathrm{E}$ & $2^{\circ} 28^{\prime} 41.9^{\prime \prime S}$ & 23 & 220 \\
\hline 7 & NMI 08/04 & $140^{\circ} 25^{\prime} 50.0 " \mathrm{E}$ & $2^{\circ} 24^{\prime} 40.2^{\prime \prime S}$ & 26 & 340 \\
\hline 8 & NMI 09/29 & $140^{\circ} 33^{\prime} 40.7 " \mathrm{E}$ & $2^{\circ} 26^{\prime} 27.7^{\prime \prime S}$ & 28 & 158 \\
\hline 9 & NMI 10/61 & $140^{\circ} 34^{\prime} 41.7 " \mathrm{E}$ & $2^{\circ} 26^{\prime} 42.9^{\prime \prime S}$ & 28 & 170 \\
\hline 10 & NMI 12/20 & 140³1'54.6"E & $2^{\circ} 26^{\prime} 12.8^{\prime \prime S}$ & 18 & 250 \\
\hline 11 & NMI 13/51/68 & $140^{\circ} 35^{\prime} 43.5^{\prime \prime E}$ & $2^{\circ} 27^{\prime} 10.6 " S$ & 23 & 260 \\
\hline 12 & NMI 15/59/66 & $140^{\circ} 37^{\prime} 44.3^{\prime \prime E}$ & $2^{\circ} 27^{\prime} 04.5^{\prime \prime S}$ & 30 & 240 \\
\hline 13 & NMI 16/33 & $140^{\circ} 30^{\prime} 54.7 " \mathrm{E}$ & $2^{\circ} 25^{\prime} 46.8^{\prime \prime S}$ & 28 & 100 \\
\hline 14 & NMI 18/41/67 & $140^{\circ} 39^{\prime} 15.5 " \mathrm{E}$ & $2^{\circ} 28^{\prime} 20.3^{\prime \prime S}$ & 25 & 390 \\
\hline 15 & NMI 19/22 & $140^{\circ} 29^{\prime} 44.8^{\prime \prime E}$ & $2^{\circ} 26^{\prime} 30.6^{\prime \prime S}$ & 27 & 110 \\
\hline 16 & NMI 21/39/43 & $140^{\circ} 40^{\prime} 17.1 " \mathrm{E}$ & $2^{\circ} 28^{\prime} 27.2^{\prime \prime S}$ & 15 & 200 \\
\hline 17 & NMI 24/55/65 & $140^{\circ} 41^{\prime} 50.1 " \mathrm{E}$ & $2^{\circ} 28^{\prime} 45.2^{\prime \prime S}$ & 28 & 261 \\
\hline 18 & NMI 27/53/58 & $140^{\circ} 42^{\prime} 48.2^{\prime \prime E}$ & $2^{\circ} 29^{\prime} 08.7^{\prime \prime S}$ & 27 & 140 \\
\hline 19 & NMI 28/34/52 & $140^{\circ} 31^{\prime} 54.6 " \mathrm{E}$ & $2^{\circ} 26^{\prime} 12.8^{\prime \prime S}$ & 18 & 250 \\
\hline 20 & NMI 32/11 & $140^{\circ} 26^{\prime} 56.4^{\prime \prime E}$ & $2^{\circ} 25^{\prime} 19.7^{\prime \prime S}$ & 20 & 220 \\
\hline 21 & NMI 36/38 & $140^{\circ} 27^{\prime} 55.0^{\prime \prime E}$ & $2^{\circ} 25^{\prime} 53.3^{\prime \prime S}$ & 22 & 132 \\
\hline 22 & NMI 35/37 & $140^{\circ} 23^{\prime} 14.0^{\prime \prime E}$ & $2^{\circ} 23^{\prime} 55.1 " \mathrm{~S}$ & 18 & 240 \\
\hline 23 & NMI 40/54/56 & $140^{\circ} 43^{\prime} 41.0^{\prime \prime E}$ & $2^{\circ} 29^{\prime} 45.8^{\prime \prime S}$ & 24.5 & 270 \\
\hline 24 & NMI 57/31 & $140^{\circ} 20^{\prime} 48.4^{\prime \prime E}$ & $2^{\circ} 23^{\prime} 40.6^{\prime \prime S}$ & 20 & 290 \\
\hline
\end{tabular}

formed at an accelerating voltage of $15 \mathrm{kV}$ and a beam current of $20 \mathrm{nA}$ on individual spectrometers equipped with crystals (TAP, LIF, PET, LPET). The standards included in the equipment of the Inter-Institutional Laboratory of Microanalysis of Minerals and Synthetic Substances of the Faculty of Geology of the University of Warsaw were used for the studies: $\mathrm{Mg}, \mathrm{Si}$, Ca-diopside; Al, K-orthoclase; V-vanadinite; Mn-rhodonite, Fe-hematite; Cu-cuprite; Zn-sphalerite; Cr-chromite; $\mathrm{Ti}_{-} \mathrm{TiO}_{2}$; $\mathrm{Na}$-albite; Ni-NiO; P-xenotime; $\mathrm{Nb}$ (metallic)-Nb. The limits of detection in ppm were as follows: Al-257; Ca-334; Cr-469; Cu-1648; Fe-1027; K-267; Mg-238; Mn-974; Na-373; Nb-541; Ni-1269; P-192; Si-270; Ti-399; V- 740; Zn-2100.

Preliminary magnetic separation was performed using a magnetic separator Franz Magnetic Barrier Laboratory Separator Model LB-1, at $0.3 \mathrm{~A}$ current intensity, $20^{\circ}$ angle of repose, and 15 and $20^{\circ}$ elongated angle of inclination.

The chemical composition of marine sediments (bulk samples or bulk analyses) was done in a certified laboratory of Bureau Veritas (BV) in Vancouver (Canada). The analyses were carried out using the LF200 and FA330 analytical programs (www.acmelab.com). Samples for the LF200 program were melted with $\mathrm{Na}_{2} \mathrm{~B}_{4} \mathrm{O}_{7} / \mathrm{Li}_{2} \mathrm{~B}_{4} \mathrm{O}$ and then dissolved in a mixture of aggressive acids. For the analysis of precious metals the Fire Assay methodology adopted in the BV laboratory was used. The analyses were carried out using optical mass and emission spectrometry coupled with inductively induced plasma
(ICP-MS and ICP-OES). The loss of ignition (LOI) was determined by roasting the sample at $1000^{\circ} \mathrm{C}$. The contents of organic carbon and elemental sulphur were determined with the LECO analyzer.

Concentrations of rare earth elements were normalized $(\mathrm{N})$ to PAAS; Post-Archean Australian Shale (McLennan, 1989). $\mathrm{Eu}$ and $\mathrm{Ce}$ anomalies were calculated from $\mathrm{Eu}_{N} / \mathrm{Eu}^{*}=2 \mathrm{Eu_{N }} /\left(\mathrm{Sm}_{\mathrm{N}}+\mathrm{Gd}_{\mathrm{N}}\right), \mathrm{Ce} / \mathrm{Ce}{ }^{*}=3 \mathrm{Ce}_{\mathrm{N}} /\left(2 \mathrm{La}_{\mathrm{N}}+\mathrm{Nd}_{N}\right)$, and $\mathrm{Ce}_{\text {anom }}=\log \left(\mathrm{Ce} / \mathrm{Ce}^{*}\right)$ formulas, which are used to determine the anomaly values for marine sediments (de Baar et al., 1985). The La-Th-Sc, Th-Co-Zr/10 and Th-Sc-Zr/10 diagrams (Bhatia and Crook, 1986) were used to determine the bedrock source.

\section{RESULTS}

\section{PETROGRAPHY OF MARINE SEDIMENTS}

Sea sediment (Fig. 2) shows local variability related to biological activity on the shelf, geological structure of the Cyclops Mountains Massif, and coastal line shape. The results of the sieve analysis of loose material (Appendix $1^{*}$ ) showed that the shelf sediment is represented by coarse-grained sands (23 samples) and medium-grained sands (20 samples); fine-grained sands (16 samples) are a smaller group. The sam-

* Supplementary data associated with this article can be found, in the online version, at doi: 10.7306/gq.1512 


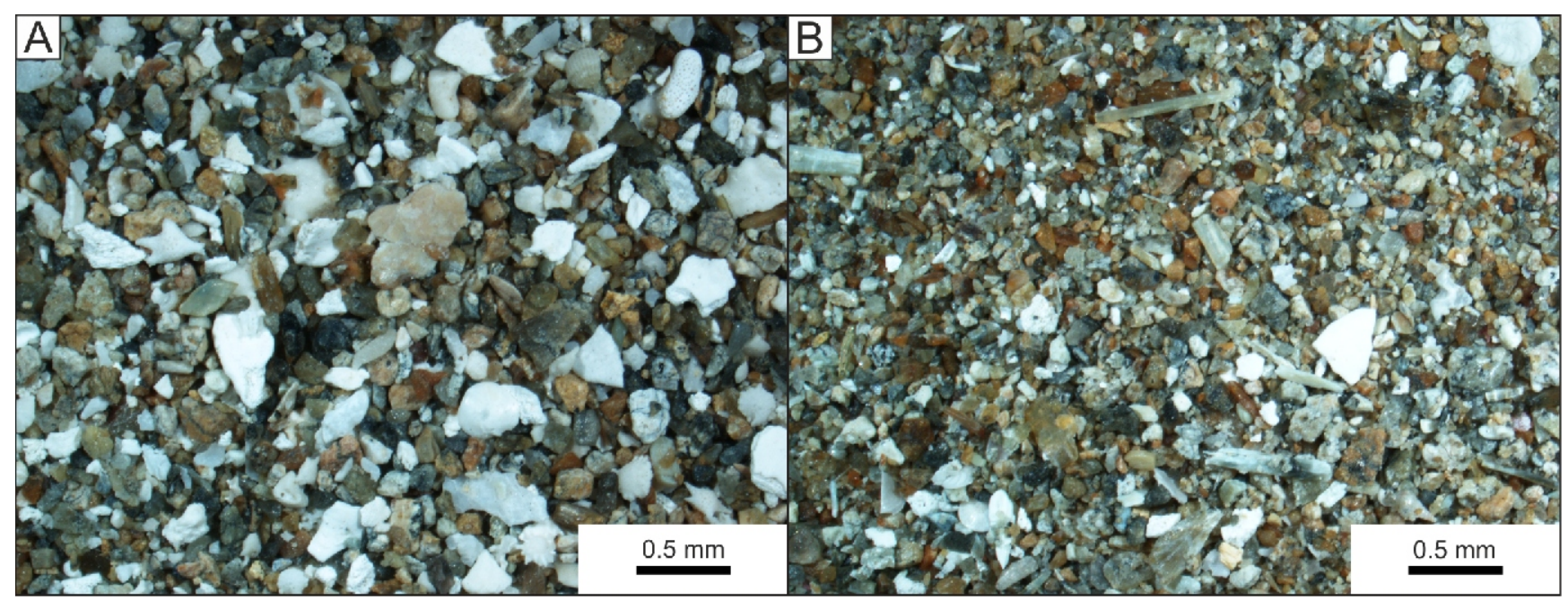

Fig. 2. Shelf sediments: A - sample JP10 and B - sample JP12, stereoscopic microscope

ples contain significant amounts (average 58.88 wt. \% of sediment) of carbonate skeletons of marine organisms, such as foraminifers, sponges, bivalves, snails and coral fragments occurring mainly in coarse- and medium-grained fractions. Terrigenous components (on average $41.12 \mathrm{wt.} \%$ ) are a less numerous group. There are no biogenic silica components.

The average content of carbonate components in coarse-grained samples is $86.69 \mathrm{wt} . \%$. The average carbonate content is 45.13 wt. $\%$ for medium-grained and 36.10 wt. $\%$ for fine-grained sediments.

Bottom sediments after the removal of marine fauna are composed of fine-grained sands (33 samples) containing $0.77-84.40$ wt. $\%$ of terrigenous components, on average 35.05 wt.\% (Appendix 2). There are no fine-grained sediments (silt and clay) as a consequence of the sampling method using a suction dredge. The content of terrigenous components is from 0.24 to $84.84 \mathrm{wt} . \%$ (average $54.87 \mathrm{wt} . \%$ ). The least numerous group of sediments are coarse-grained sands (5 samples) with an invariable content of detrital components. The content of terrigenous components in the coarse-grained samples varies from 19.36 to $39.60 \mathrm{wt} . \%$.

\section{THE MINERALOGY OF MARINE SEDIMENTS}

Mineral composition of the shelf sediments shows spatial diversity within the whole examined seabed along the coast. The presence of light minerals (21.58 wt. \%) and heavy minerals (20.37 wt.\%) was found in the sediments (Fig. 3). Barren and ore minerals were separated from the heavy mineral fractions. Heavy minerals dominate in the grain class $0.1-0.25 \mathrm{~mm}$. The content of heavy fraction is up to $54.77 \%$ of the sediment mass.

Phase analysis of seabed sediments from the northeastern coast revealed the presence of calcite, aragonite, halite, quartz, plagioclases and talc. The group of heavy minerals consists of siderite, garnet, pyroxene, serpentine, olivine, chrome spinels and magnetite. Tungsten minerals have not been observed. The samples contain fragments of limonite clasts. Bottom sediments from the central coastal zone are characterized by a different mineral composition. Within the seabed from the central part of the coast, two zones - eastern and western - have been identified. The bottom sediment in the eastern section is dominated by aragonite, halite, calcite and talc. The heavy components are olivine, pyroxenes, and minerals of the serpentine group. Useful minerals are represented by chromium spinels, magnetite, copper and iron sulphides, rutile and hematite. In the western section, the mineral complex consists of albite, aragonite, biotite, calcite, quartz, muscovite and plagioclase. The heavy mineral complex consists of amphiboles, epidotes, clinochlore, pyroxene, siderite and titanite. Ore minerals include ilmenite, hematite, magnetite, rutile and copper and iron sulphides. The bottom sediment extracted from the north-western part of the coast is characterized by the presence of aragonite, calcite, halite and talc. The group of heavy and complex minerals comprises amphiboles, olivine, chrome spinels, magnetites, pyroxenes and serpentine group minerals.

\section{GEOCHEMISTRY OF MARINE SEDIMENTS}

The chemical composition of shelf sediments shows wide lateral differentiation along the whole coastline (Appendix 3). Marine sediments from the northeastern part of the coast, in contrary to the upper continental crust (Rudnick and Gao, 2003), were enriched in strategic metals (Appendix 4): Ni up to $3561 \mathrm{ppm}, \mathrm{W}$ up to $3130 \mathrm{ppm}$, and Co 47-142 ppm, and significantly impoverished in LILE (Large-lon Lithophile Elements). Samples JP6 and JP7 show a clear enrichment in Sr up to $3231.5 \mathrm{ppm}$. Increased contents of $\mathrm{MgO}$ 16.25-38.33 (wt.\%) and $\mathrm{Cr}_{2} \mathrm{O}_{3} 0.849$ (wt.\%) are found in the sediments. In contrary to the samples from the eastern part of the coast, the marine sediment from the central and western zones is characterized by increased contents of $\mathrm{Cu} 7-28 \mathrm{ppm}, \mathrm{V}$ 41-244 ppm, $\mathrm{Zr} 12-55 \mathrm{ppm}$ and $\mathrm{TiO}_{2}$ up to $0.78 \mathrm{wt} . \%$. The sediment is enriched in LILE. The samples show a heterogeneous distribution of TOT/C values from 0.07 to $8.26 \%$. The TOT/S is homogeneous throughout the coastline. The loss on ignition (LOI) for the sediments ranges from 2.5 to $31.1 \%$.

The contents of precious metals do not exceed normally the lower detection limit of the test method used. The maximum contents in shelf sediments for Au are up to $3.8 \mathrm{ppb}$, Pt up to $9 \mathrm{ppb}$, and $\mathrm{Pd}$ up to $8 \mathrm{ppb}$. There are increased contents of $\mathrm{Ag}$ up to $5 \mathrm{ppm}$.

The distribution of REE in shelf sediments was analysed (Fig. 4). There is a strong impoverishment of REE in relation to PAAS in all samples. Two groups of sediments have been identified based on the REE content results. The first group excavated from the central and western coastal zone is character- 


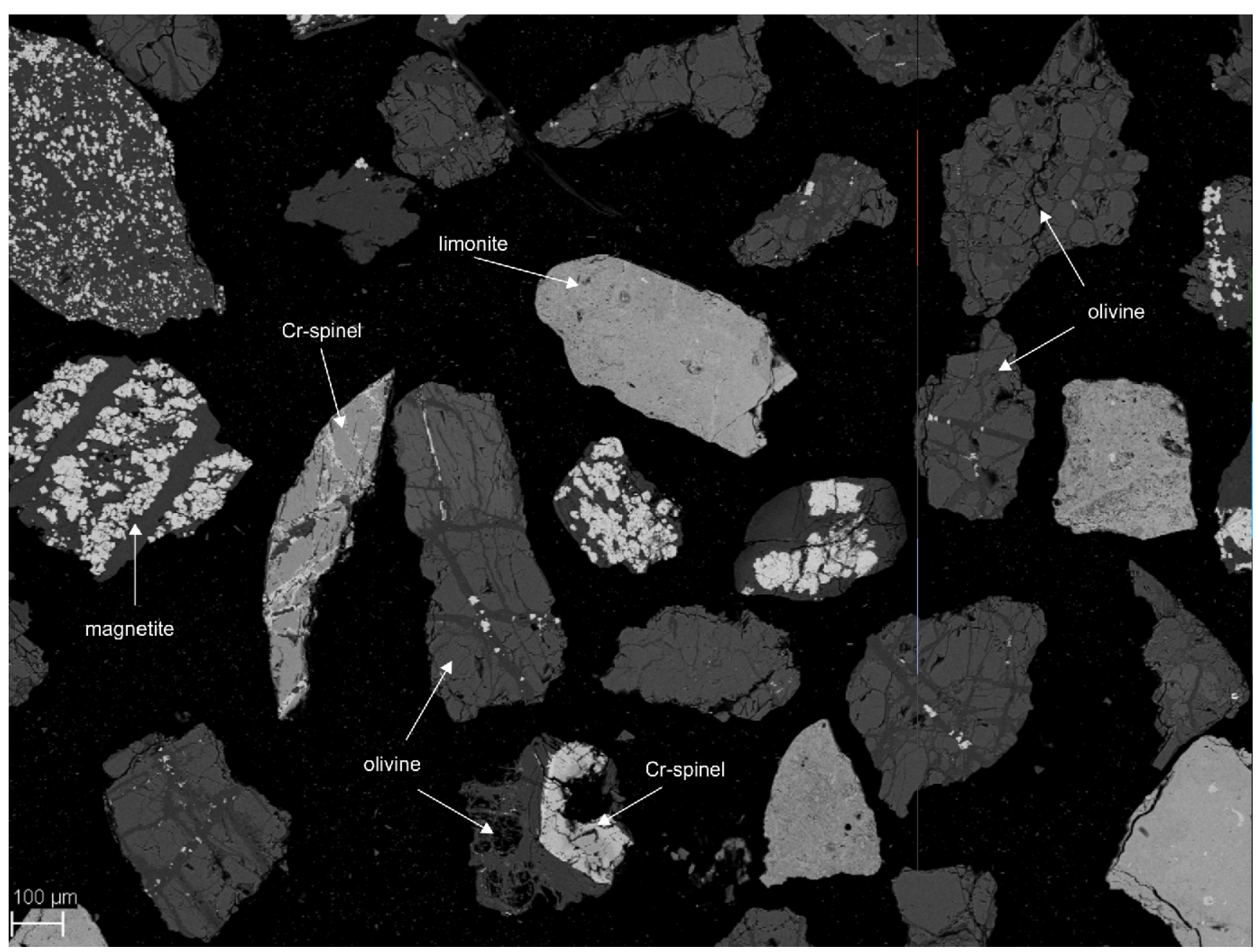

Fig. 3. Mineral composition of the shelf sediments, sample JP12, SEM-BSE image

ized by a regular distribution of REE. The $\Sigma$ REE content is in the range of 15.12-99.26 ppm, $\Sigma$ LREE $6.52-50.27 \mathrm{ppm}$, and $\Sigma$ HREE 8.60-54.03 ppm. A negative anomaly for Ce and positive for Eu was found. In two samples (JP29, JP49) a positive Ce anomaly appears. MREE and HREE are characterized by a regular distribution of the content with a slight $\mathrm{Yb}$ fluctuation.

The second group of samples from the eastern part of the coast indicates the lack of clear homogenization. The $\Sigma$ REE content is in the range of $1.4-4.53 \mathrm{ppm}, \quad \Sigma \mathrm{LREE}$ 1.10-3.34 ppm, $\Sigma$ HREE 0.30-1.53 ppm. Positive Eu and negative/positive Ce anomalies, and negative $\mathrm{Pr}, \mathrm{Sm}$ and $\mathrm{Er}$ anomalies are present in the samples. Depletion of HREE is identified in the sediment.

\section{DISCUSSION}

\section{THE SOURCE OF CONTEMPORARY MARINE SEDIMENTS}

REE distribution in shelf sediments is an important indicator of material source (Table 2) and differentiation processes (Kazuhiro et al., 1990; Terry and Charles, 1998; Pramod and Rajamani, 2001; Yang et al., 2002). Terrigenous sediments deposited in the coastal environment show REE curves similar to their land counterparts of parent rocks (Cullers and Podkovyrov, 2000; Yan et al., 2010; Piper and Bau, 2013) due to poor fractionation during transport (Yang et al., 2003). Stan- dardization of the extracted samples against PAAS (Fig. 4) indicates two sources of the original material. The group of sediments extracted from the western and eastern parts of the coast has a very low REE content. Low concentrations of MREE and HREE are characteristic for residual peridotites. The calculated values correlate with the results of analyses obtained by Monnier et al. (1999). Positive and negative anomalies of cerium were recorded in the sediments. The presence of the anomalies may indicate redox conditions on the continental shelf. Negative anomaly may indicate a supply of "freshly deposited" sediment that has not yet been oxidized. The second group of sediments shows a homogeneous decomposition of REE with a small Eu anomaly. The homogeneous value correlates with the REE decomposition of the Cyclops Mountains metamorphic core

The study of the mineral composition of beach sediments allowed separating three subprovinces that differ in the character of parent rocks' source. Shelf sediments from the eastern and western parts of the coast contain minerals typical for rocks of the mafic/ultramafic environment - chromium spinels, Mg-olivine, serpentine group minerals, and limonite fragments. Research on mafic rocks conducted by the Monnier et al. (1999) and on chromium spinels conducted by Zglinicki (2016) reveals that the minerals in seabed sediments in the eastern and western parts of the coast originate from rocks of the ophiolite sequence formed under supra-subduction environment conditions. The occurrence of amphibole, epidote and clinochloride 


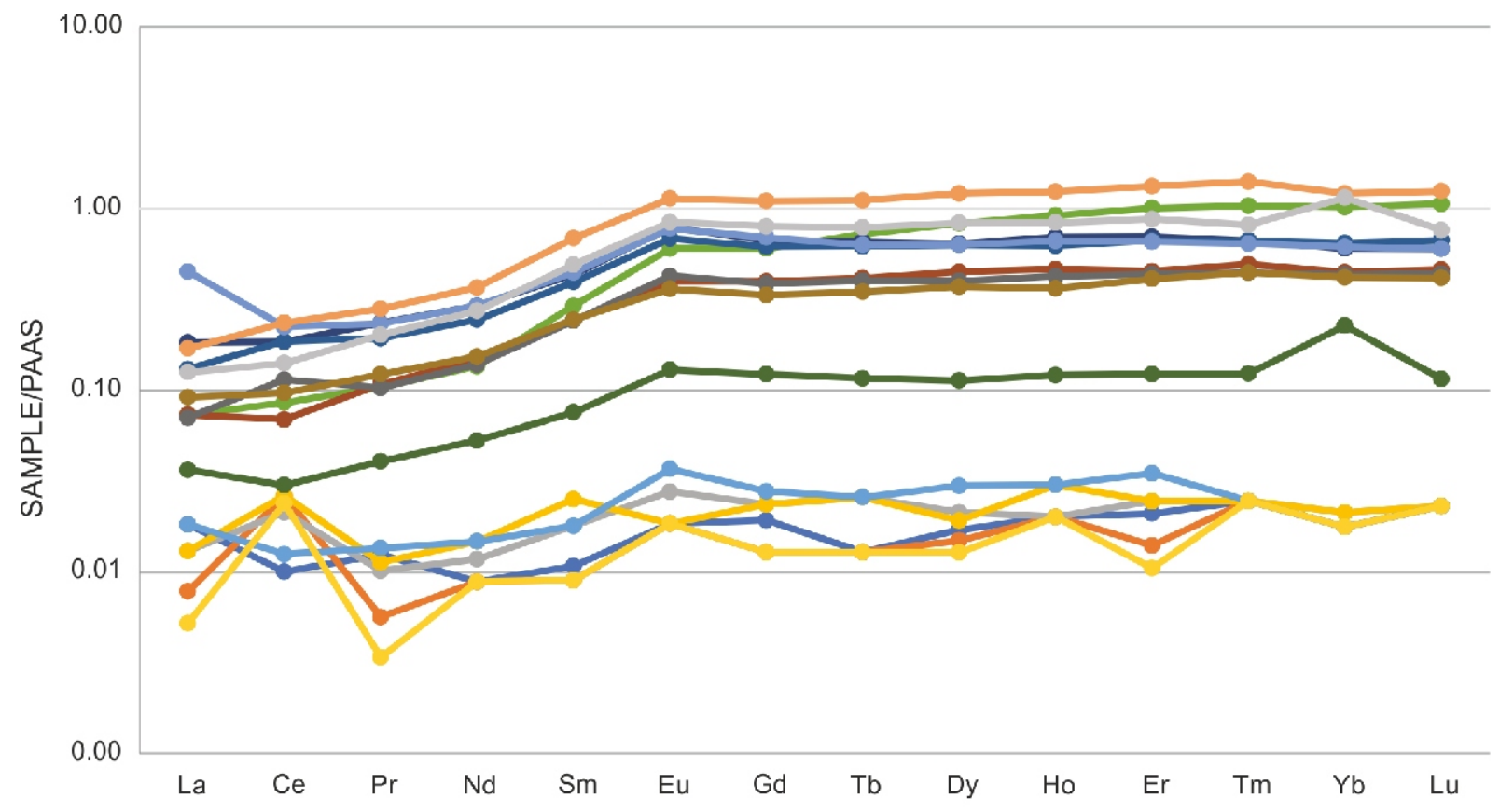

Fig. 4. PAAS-normalized REE diagram for the coastline sediments

Comparison of average ratios and total REE contents in coastal sediments from Jayapura-related rocks with average REE contents of modern tectonic environments

\begin{tabular}{|l|c|c|c|c|c|}
\hline \multicolumn{1}{|c|}{ Tectonic settings } & $(\mathrm{La} / \mathrm{Yb})_{\mathrm{N}}$ & $(\mathrm{La} / \mathrm{Sm})_{\mathrm{N}}$ & $(\mathrm{Gd} / \mathrm{Yb})_{\mathrm{N}}$ & $\mathrm{Eu} \mathrm{Eu}^{*}$ & $\Sigma \mathrm{REE}$ \\
\hline Oceanic Island $\mathrm{Arc}^{1}$ & $2.9 \pm 0.9$ & - & - & $1.04 \pm 0.11$ & 58 \\
\hline Passive Margin $^{2}$ & 9.80 & 3.67 & 1.40 & 0.74 & 106.83 \\
\hline Back Arc Basin $^{2}$ & 6.50 & 2.95 & 1.30 & 0.79 & 83.63 \\
\hline Continental Arc Basin $^{2}$ & 7.18 & 3.19 & 1.30 & 0.76 & 113.49 \\
\hline Marine Sediments from Jayapura $^{3}$ & 0.33 & 0.57 & 0.91 & 0.21 & 33.56 \\
\hline
\end{tabular}

${ }^{1}$ average data from Bhatia (1983); ${ }^{2}$ average data from McLennan et al. (1990); ${ }^{3}$ average data from this research

minerals in shelf sediments in the central part of the coast coincides with the results of studies conducted by Zwierzycki (1921), Gisolf (1921), Baker (1955, 1956), Monnier et al. (1999) and Zglinicki (2016). The presence of the minerals indicates a metamorphic nature of the source area.

Trace elements (Th, Sc, Zr, REE) were used to determine the provenance of shelf sediments. These elements are an excellent tool for determining the source of parent rocks due to their low solubility and mobility during weathering, transport and diagenesis. At the same time, they retain the features of parent rocks in the sedimentological record. The La/Th vs. Hf ratio (Floyd and Leveridge, 1987) is an indicator used to determine the source of parent rocks. The $\mathrm{Hf}$ and Th contents in sediments from the east coast are below the lower detection limit of the used test method (ICP-MS). The values calculated for central coastal sediments indicate that the source is the rocks formed from andesite magma associated with island arcs. The $\mathrm{La} / \mathrm{Th}$ index for West Coast sediments is typical for the tholeiitic magma sequence of islands arcs. The geochemistry of the shelf sediments may be related directly to tectonic processes leading to the generation of parent rocks. On the La-Th-Sc, Th-Co-Zr/10 and Th-Sc-Zr/10 diagrams (Bhatia and Crook, 1986; Fig. 5) the geotectonic position of parent rocks has been determined. The obtained values indicate that the parent rocks are associated with the active oceanic island arc.

\section{INFLUENCE OF MARINE CONDITIONS} ON HEAVY MINERAL CONCENTRATIONS

The dynamics of deposit-forming processes, leading to the concentration of heavy minerals in the coastal environment, is diversified both between individual basins and within a single basin. There is no single universally accepted depositional model for offshore deposits. Mechanical and chemical weathering processes, hydraulic sorting, abrasion and dissolution may lead to significant concentrations of heavy minerals in marine sediments with characteristic features (Smirnow, 1986; Depowski et al., 1998; Van Gosen et al., 2014). 

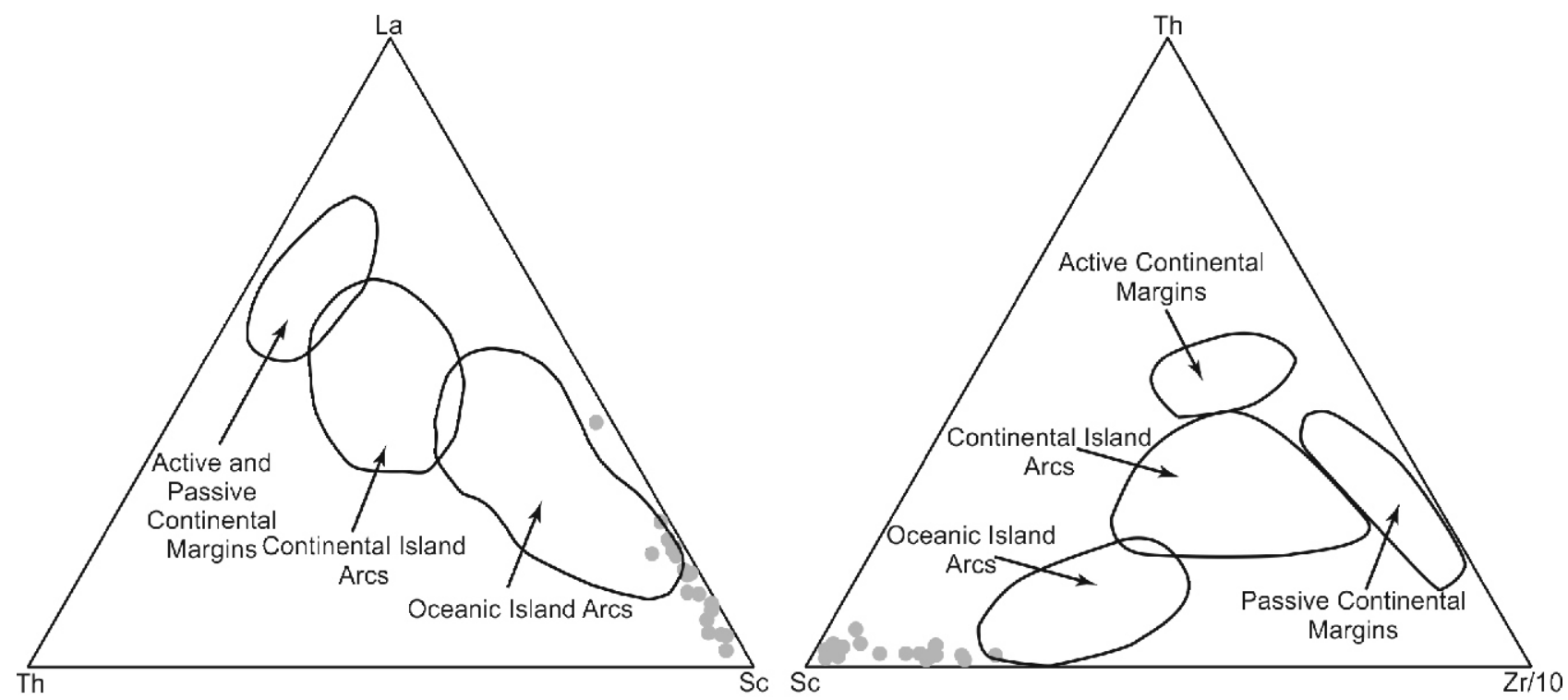

Fig. 5. Discrimination plots La-Th-Sc and Th-Sc-Zr/10 for tectonic settings (after Bathia and Crook, 1986)

Tectono-eustatic changes in the late Pleistocene sea level shaped the contemporary coastline of the Jayapura region (Verstappen, 1975). The sea level rise is usually accompanied by a gradual migration of coastal morphodynamic barriers. The migration of forms enriched in heavy mineral layers can lead to a concentration of economically important useful components. The preservation of structures enriched in heavy minerals is possible when the migratory forms are trapped, e.g., in coastal longitudinal channels (Tixeront, 1978). The landward transport of rich layers of heavy minerals is accompanied by a clear decrease in heavy mineral content as a function of depth and distance. It is confirmed by the Australian shelf model proposed by Kudrass (1987). A similar dependence exists in the coastal sediments of the northern coast of New Guinea. The energy distribution of wave processes along the entire coastline is heterogeneous. This results in a variable wave base surface below which the kinetic energy of the waves does not initiate the movement of the material towards the shore. The uneven influence of wave processes significantly affects the regional differentiation of heavy mineral content as a function of depth and distance from land. Fractional sedimentation is caused by coastal currents from the eastern part of the Jayapura district. In the case of coastal sediments, a linear decrease in heavy mineral content with increasing water depth is evident. The visible degression of the heavy fraction is below the isobathic level of 27 metres below the sea-floor ( $m$ b.s.f.). The share of heavy minerals in the sediment weight is $45.76 \%$, while at the isobath of $30 \mathrm{~m}$ b.s.f. - only $5.73 \%$. The greatest amount of heavy minerals is recorded at a depth of 23 to $27 \mathrm{~m}$ b.s.f. The heterogeneity of the sediments is also visible in relation to the distance from land. The linear degeneration of heavy minerals takes place at a distance of $\sim 260 \mathrm{~m}$ from the coast. The average heavy mineral content drops from 48.33 to 0.21 wt. $\%$ at point $460 \mathrm{~m}$ from the land border. The greatest share of the heavy fraction in seabed sediments occurs at distances between 200 and $300 \mathrm{~m}$. The concentration of heavy minerals also depends on the sea-bottom slope angle. This angle has not been studied.

\section{MINERAL DEPOSIT POTENTIAL OF SHELF SEDIMENTS}

Poorly consolidated, moderately graded medium to fine sands enriched with heavy minerals can be a useful mineral. The accumulation of the heavy fraction has a polymineral character, laterally differentiated. The dominant grain class of the heavy fraction is grains with a particle size of $0.1-0.25 \mathrm{~mm}$. The spectrum of high-density minerals consists of amphiboles, biotite, chromium spinel, epidote, hematite, clinochlore, Mg-olivines, serpentine group minerals, pyroxenes, rutile, copper and iron sulphides, titanite, and limonite fragments. The grains of heavy minerals form characteristic paragenesis of various features, e.g. from substitution, mixing, in the form of irregular veins. The shape of the textures directly influences the technology and costs of mineral processing. The fraction of heavy minerals underwent magnetic separation (Fig. 6), obtaining a concentrate of magnetic and weakly magnetic minerals. The fraction of strongly magnetic minerals is composed mostly of magnetite. Less magnetic minerals are composed of olivine (with paragenesis of magnetite and chromium spinel), chromium spinel (with paragenesis of magnetite), hematite and amphibole with ilmenite. The non-magnetic group consists of the other components in the sediment (plagioclase, micas, epidotes).

A prospective mineral for the heavy fraction in the seabed sediment is chromium spinel. The percentage of the mineral in the entire coastline is variable. In the eastern part of the coast at the sampling sites, homogeneous chromite grains are on average $7.36 \%$ of the heavy fraction, and in paragenesis with olivine and magnetite: 1.44 and $2.70 \%$, respectively. In the central part, which is an extension of the eastern subprovince, the content of homogeneous chromium spinel grains is on average of $4.98 \%$, co-existing with magnetite $1.22 \%$ and olivine $0.02 \%$. The western mineral subprovince is characterized by an average chromium spinel grain content of $2.71 \%$, with magnetite $0.93 \%$ and olivine $0.79 \%$. 


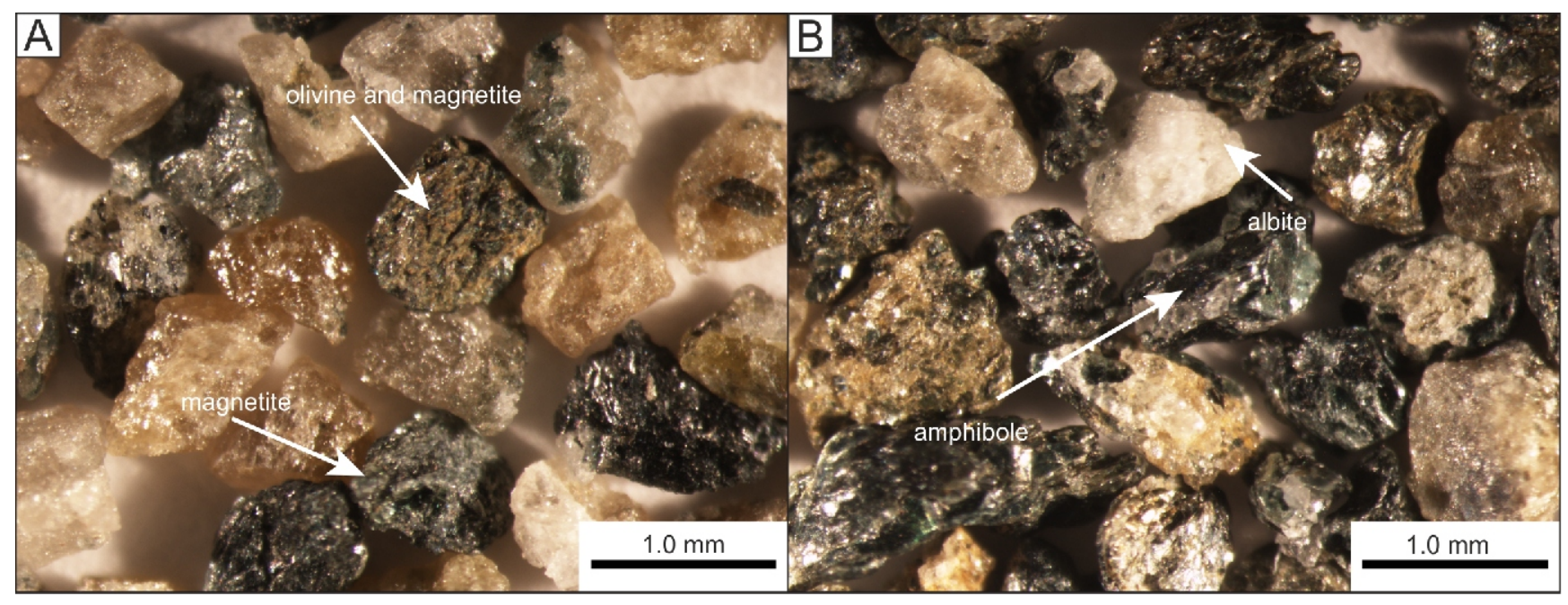

Fig. 6. Grains obtained from magnetic separation

(A) sample JP8 and (B) sample JP41; stereoscopic microscope; magnification $\times 2$

MINERALOGICAL-GEOCHEMICAL SUBPROVINCES

The spatial diversity of seabed sediments from the Jayapura coast is the result of the heterogeneous geological structure of the region. The heterogeneous mineral composition of the terrigenous sediments along the whole coastline determines the presence of three mineralogical subprovinces with a variable character of the source area.

The eastern and western subprovinces are characterized by minerals from mafic and ultramafic rocks: Mg-olivines, pyroxenes, serpentine group minerals, and limonite fragments. Ore minerals are represented by chromite, magnetite and small amounts of hematite.

The central subprovince is characterized by the presence of minerals from the metamorphic environment. The phase composition of the flat-bottomed sediments of the northern coast of New Guinea corresponds to the mineralogy of the rocks of the Jayapura region. The group of heavy minerals includes amphiboles, biotite, epidote, clinochlore, pyroxenes and titanite. The useful minerals are represented by magnetite, ilmenite, hematite, rutile, and copper and iron sulphides.

The mineralogy of the seabed surface sediments of the Jayapura coast correlates with the phases described onshore by Zwierzycki (1921), Gisolf (1921), Baker $(1955,1956)$ and Monnier et al. (1999).

The concentrations of elements in bottom sediments are particularly correlated with the occurrence of mineral subprovinces. The central part of the source area, composed of metamorphic rocks, is a zone of accumulation of elements characteristic for minerals present in these rocks. This zone shows increased values of the local geochemical background for $\mathrm{Cu}, \mathrm{K}$, $\mathrm{Mn}, \mathrm{Sr}, \mathrm{Ti}, \mathrm{Zr}, \mathrm{REE}$, and $\mathrm{V}$. In the eastern and western parts of the coast, increased contents of $\mathrm{Co}, \mathrm{Cr}, \mathrm{Fe}, \mathrm{Ni}$ and $\mathrm{Zn}$ were found. The accumulation of elements is characteristic for mafic and ultramafic rocks, which are a source for the sediments of the eastern and western coasts of Jayapura.

\section{PRELIMINARY GEOLOGICAL AND MINERAL DEPOSIT PROSPECTS}

The sediments analysed in the study contain chromium and tungsten. At the current preliminary recognition level (58 samples from the seabed surface) it is impossible to determine the criteria of minimum abundances and average contents of useful components. Based on the mineral deposit forecasts (Fig. 7), it can be assumed that the sediment enriched with chromium and tungsten occurs in two blocks ( $A$ and $B$ ) covering 29.7 and $15.2 \mathrm{~km}^{2}$, respectively. Due to lack of data, the exploratory works should be carried out in two subprovinces (western and extended eastern) excluding the central non-prospective zone. Based on the contemporary exploration results the resources were determined as inferred (based on JORC Code). For more detailed recognition it is necessary to perform sediment probing on the seabed of the designated area in the future. The operations should cover the area of the narrow continental shelf. The probing stage should be preceded by a survey of the basin seabed surface. An irregular seabed surface of the shelf is expected, with numerous narrow channels facing the New Guinea Trench.

\section{CONCLUSIONS}

1. The mineralogical-geochemical studies of shelf sediments have shown that the contemporary shallow-water sediments of the Jayapura coast are derived from rocks of the ophiolite sequence and metamorphic core of the Cyclops Mountains. The values of function discrimination indicate that the Cyclops Mountains Massif was formed under the conditions of oceanic islands arc. This is confirmed by research conducted by Monnier et al. (1999) and Zglinicki (2016).

2. Depending on the sampling site, the sediment shows significant differences in colour, grain size and presence of organic components. The variability is the result of regional differentiation 


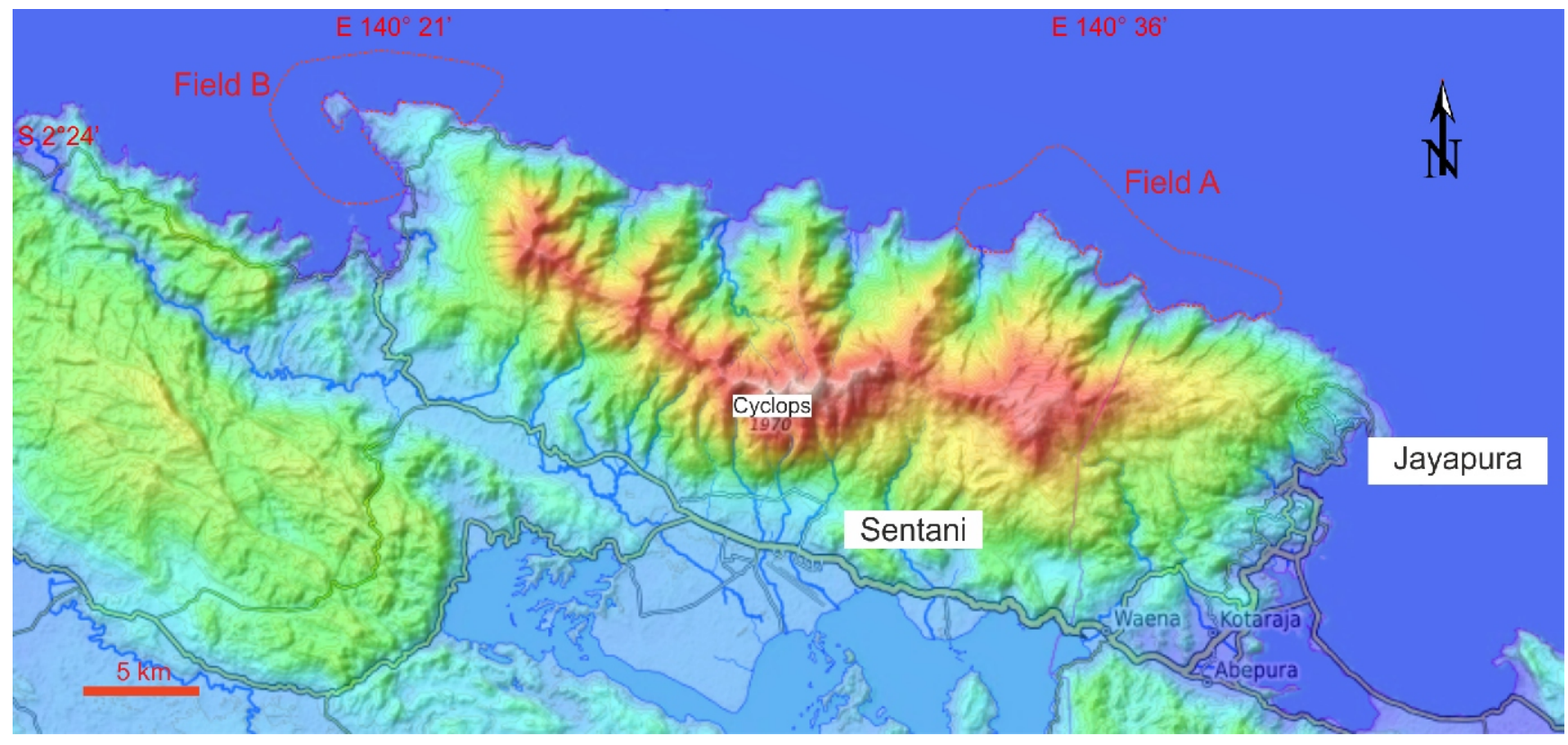

Fig. 7. Prospective fields

Two blocks (A and B) covering 29.7 and $15.2 \mathrm{~km}^{2}$, respectively

in the coastline morphology, coastline processes, and the source of the material. The detrital sediment (after carbonate removal) is represented by coarse-, medium- and fine-grained sands.

3. The heavy fraction accumulated in the sediment has a polymineral character (amphiboles, chromium spinel, epidote, hematite, ilmenite, clinochlore, magnetite, serpentine group minerals, olivine, pyroxenes, rutile, copper and iron sulphides, titanite). Heavy minerals in the seabed sediment show lateral differentiation along the entire coastline.

4. The spatial analysis of the mineral composition of the sediments allowed determining three subprovinces with different source areas. The eastern and western subprovinces are characterized by a mafic and ultramafic source of material origin. The central zone is represented by sediments of metamorphic origin. The geochemical diversity correlates with the mineral composition.
5. The occurrence of individual elements coincides with the mineral subprovinces identified. In the central zone there is enrichment with $\mathrm{Ba}, \mathrm{Cu}, \mathrm{V}, \mathrm{Zr}, \mathrm{Sr}, \mathrm{REE}$ and $\mathrm{Ti}$. The eastern and western zones are characterized by the $\mathrm{Cr}-\mathrm{Ni}-\mathrm{Co}-\mathrm{W}$ geochemical association.

6. Poorly consolidated, moderately sorted, medium- and fine-grained sands enriched in heavy minerals (heavy mineral content from 0.10 to $54.77 \mathrm{wt}$ \%) may be a potential useful mineral deposit. Chromium spinels are of significant importance for the deposit. The average content of heavy minerals in the seabed surface sediments is $11.5 \%$.

Acknowledgements. The authors would like to thank the reviewers of the manuscript: K. Galos and P. Lis for their valuable suggestions. Prof. R. Kotliński is acknowledged for inspiring consultations.

\section{REFERENCES}

Baker, G., 1955. Part I distribution, nature and chemical composition of the basement complex rocks. nova guinea, new ser., 6 307-328.

Baker, G., 1956. Part II opaque minerals in the basement complex rocks. Nova Guinea, new ser., 7: 15-31.

Bhatia, M.R., 1983. Plate tectonics and geochemical composition of sandstones. The Journal of Geology, 91: 611-627.

Bhatia, M.R., Crook, K.A.W., 1986. Trace element characteristics of greywackes and tectonic setting discrimination of sedimentary basins. Contributions to Mineralogy and Petrology, 92 : 181-193.

Blott, S.J., Pye, K., 2001. Gradistat: a grain size distribution and statistics package for the analysis of unconsolidated sediments. Earth Surface Processes and Landforms, 26: 1237-1248.
Cloos, M., Sapiie, B., Quarles van Ufford, A., Weiland, R.J., Warren, P.Q., McMahon, T.P., 2005. Collisional delamination in New Guinea: The geotectonics of subducting slab breakoff. GSA Special Papers, 400: 1-51.

Cullers, R.L., Podkovyrov, V.N., 2000. Geochemistry of the Mesoproterozoic Lakhanda Shales in southeastern Yakutia, Russia: Implications for mineralogical and provenance control recycling. Precambrian Research, 104: 77-93.

Davies, H.L., 2012. The geology of New Guinea - the cordilleran margin of the Australian continent. Episodes, 35: 87-102.

De Baar, H.J.W., Bacon, M.P., Brewer, P.G., Bruland, K.W., 1985. Rare earth elements in the Pacific and Atlantic Oceans. Geochimica et Cosmochimica Acta, 49: 1943-1959. 
Depowski, S., Kotliński, R., Rühle, E., Szamałek, K., 1998 Surowce mineralne mórz i oceanów (in Polish). Wydawnictwo Scholar, Warszawa.

Dergatchev, A.L., Eemin, N.I., Sergeeva, N.E., 2011. Volcanic-associated Besshi-type copper sulfide deposits. Moscow University Geology Bulletin, 66: 274-281.

Floyd, P.A., Leveridge, B.E., 1987. Tectonic environment of the Devonian Gramscatho Basin, South Cornwall: framework mode and geochemical evidence from turbiditic sandstones. Journal of the Geological Society, 144: 531-542.

Garzanti, E., Andò, S., 2007. Heavy mineral concentration in modern sands: implications for provenance interpretation. Developments in Sedimentology, 58: 517-541.

Gisolf, W.F., 1921. Microscopisch onderzoek van gesteenten van Noord-Nieuw-Guinea. Jaarboek v.h. Mijnwezen in Nederl. Oost-Indië. Verhandelingen, eerste gedeelte: 133-161.

Hamilton, W., 1979. Tectonics of the Indonesian region. U.S. Geological Survey Prof. Paper, 1078.

Kazuhiro, T., Nakamura, Y., Masuda, A., 1990. Rare earth elements of Pacific pelagic sediments. Geochimica et Cosmochimica Acta, 54: 1093-1103.

Kotliński, R.A., 2001. Mineral resources of the world's ocean - their importance for global economy in the 21st century. In: Proceedings of 4th ISOPE Ocean Mining Symposium: 1-7. Szczecin, Poland: International Society for Offshore and Polar Engineers.

Krause, D.C., 1965. Submarine geology north of New Guinea. GSA Bulletin, 76: 27-42

Kudrass, H.R., 1987. Sedimentary models to estimate the heavy-mineral potential of shelf sediments. Marine Minerals, 194: $39-56$

Liu, Z., Wang, H., Hantoro, W.S, Sathiamurthy, E., Colin, C. Zhao, Y., Li, J., 2012. Climatic and tectonic controls on chemical weathering in tropical Southeast Asia (Malaya Peninsula, Borneo and Sumatra). Chemical Geology, 291: 1-12.

McLennan S., 1989. Rare earth elements in sedimentary rocks; influence of provenance and sedimentary processes. Reviews in Mineralogy and Geochemistry, 21: 169-200.

McLennan, S.M., Taylor, S.R., McCulloch, M.T., Maynard, J.B., 1990. Geochemical and Nd-Sr isotopic composition of deep-sea turbidites: crustal evolution and plate tectonic associations. Geochimica et Cosmochimica Acta, 54: 2015-2050.

Miller, A.J., Kuehl, S.A., 2009. Shelf sedimentation on a tectonically active margin: a modern sediment budget for Poverty continental shelf, New Zealand. Marine Geology, 270: 175-187.

Milliman, J.D., 1995. Sediment discharge to the ocean from smal mountainous rivers: the New Guinea example. Geo-Marine Letters, 15: 127-133.

Milliman, J.D., Syvitski, P.M., 1992. Geomorphic/tectonic control of sediment discharge to the Ocean: the importance of small mountains rivers. The Journal of Geology, 100: 524-544.

Monnier, C., Girardeau, J., Pubellier, M., Polve, M., Permana, H., Bellon, H., 1999. Petrology and geochemistry of the Cyclops ophiolites (Irian Jaya-East Indonesia): consequences for the evolution of the North Australian margin during Cenozoic. Mineralogy and Petrology, 65: 1-28.

Morton, C.A., Hallsworth, C., 1994. Identifying provenance-specific features of detrital heavy mineral assemblages in sandstones. Sedimentary Geology, 90: 241-256.

Morton, C.A., Hallsworth, C., 1999. Processes controlling the composition of heavy mineral assemblages in sandstones. Sedimentary Geology, 124: 3-29.

Morton, C.A., Smale, D., 1990. The effects of transport and weathering on heavy minerals from the Cascade River, New Zealand Sedimentary Geology, 68: 117-123.

Mosier, D.L., Singer, D.A., Moring, B.C., Galloway, J.P., 2012. Podiform chromite deposits-database and grade and tonnage models. U.S. Geological Survey Scientifc Investigations Report 2012-5157, 45 p. and database.

Peta Sebaran Bahan Galian Dan Potensi Hidrokarbon Propinsi Irian Jaya, 1995. Skala 1:2,000,000. Kantor Wilayah Departemen Pertambangan Dan Energi Propinsi Irian Jaya.
Pieters, P.E., Ryburn, R.J., Trail, D.S., 1979. Geological reconnaissance in Irian Jaya, 1976 and 1977. Department of National Development, Bureau of Geology and Geophysics and Mineral Resources, Canberra.

Piper, D.Z., Bau, M., 2013. Normalized Rare Earth Elements in water, sediments, and wine. Identifying Sources and Environmental Redox Conditions American Journal of Analytical Chemistry, 4: 69-83.

Pramod, S., Rajamani, V., 2001. REE geochemistry of recent clastic sediments from the Kaveri floodplains, southern India: implication to source area weathering and sedimentary processes. Geochimica et Cosmochimica Acta, 65: 3093-3108.

Pubellier, M., Monnier, C., Maury, R., Tamayo, R., 2004. Plate kinematics, origin and tectonic emplacement of supra-subduction ophiolites in SE Asia. Tectonophysics, 392: 9-36.

Rosa, F., Rufino, M.M., Ferreira, Ó., Matias, A., Brito, A.C. Gaspar, M.B., 2013. The influence of coastal processes on inner shelf sediment distribution: the Eastern Algarve Shelf (Southern Portugal). Geologica Acta, 11: 59-73.

Rudnick, R.L., Gao, S. 2003. The composition of the continental crust. Treatise on Geochemistry - The Crust, 3: 1-64.

Sato, T., 1977. Kuroko deposits: their geology, geochemistry and origin. Geological Society, London, Special Publications, 7: 153-161.

Smirnow, W.I., 1986. Geologia złóż kopalin użytecznych (in Polish). Wyd. Geol., Warszawa.

Sun, W., Wang, J., Zhang, Li., Zhang, Ch., Li, H., Ling, M., Ding, X., Li., C., Lian, H., 2017. The formation of porphyry copper deposits. Acta Geochimica, 36: 9-15.

Szamałek, K., Mizerski, W., 2011. Surowce mineralne z dna mórz i oceanów - stan rozpoznania i perspektywy (in Polish). Górnictwo i Geoinżynieria, 35: 353-370.

Szamałek, K., Konopka, G., Zglinicki, K., MarciniakMaliszewska, B., 2013. New potential source of rare earth elements. Gospodarka Surowcami Mineralnymi - Mineral Resources Managment, 29: 59-76.

Szamałek, K., Zglinicki, K., Konopka, G., MarciniakMaliszewska, B., 2015. Osady okruchowe strefy płytkowodne oraz plażowej wybranych regionów Indonezji. Górnictwo Odkrywkowe, 56: 14-20.

Szamałek, K., Uścinowicz, Sz., Zglinicki, K., 2018. Rare earth elements in Fe-Mn nodules from the Southern Baltic Sea - a preliminary study. Biuletyn Państwowego Instytutu Geologicznego, 472: 199-212.

Terry, C.H., Charles, H., 1998. The chemical composition of subducting sediment and its consequences for the crust and mantle. Chemical Geology, 145: 325-394.

Thirnbeck, M.R., 2001. The Sentani and Siduarsi nickel-cobalt laterite deposits, Northeast Irian Jaya, Indonesia. In: Proc. PNG Geology, Exploration and Mining Conference (eds. G. Hancock) Australasian Inst. Mining Metall., Melbourne.

Thirnbeck, M.R., 2004. A search for gold in Indonesian New Guinea. In: Proc. PACRIM 2004 Conf., Hi tech and world competitive mineral success stories around the Pacific Rim, Adelaide 2004, Australasian Inst. Mining Metall., Parkville.

Tixeront, M., 1978. French activities in the exploration for placers on the continental shelves. International seminar on offshore mineral resources. Orleans, France: Germinal and BRGM: 167-184.

Tregoning, P., Gorbatov, A., 2004. Evidence for active subduction at the New Guinea Trench. Geophysical Research Letters, 31: $1-4$.

Ubaghs, Ir.J.G.H., 1955. Mineral deposits in the Cyclops Mountains, Netherlands New Guinea. Nova Guinea, new ser., 6: $167-175$.

UNCLOS - United Nations Convention on the Law of the Sea of 10 December 1982. https://www.un.org/Depts/los/convention_agreements/convention_overview_convention.htm

Van Gosen, B.S., Fey, D.L., Shah, A.K., Verplanck, P.L., Hoefen, T.M., 2014. Deposit model for heavy-mineral sands in coastal environments. U.S. Geological Survey Scientific Investigations Report. 
Verstappen, H., 1975. On palaeoclimates and landform development in Malaysia. In: Modern Quatornary Research in Southeast Asia (eds. G.J. Bartstra et al.): 3-35.

Wentworth, C.K., 1922. A scale of grade and class terms for clastic sediments. The Journal of Geology, 30: 377-392.

Wołkowicz, S., Paulo, A. 2019. Blue mining in the Atlantic Ocean-arealneed or a need for realism? (in Polish with English summary). Przegląd Geologiczny, 67: 91-103.

Yan, B., Yan, W., Miao L., Huang L., Chen, Z., 2010. Geochemical characteristics and provenance implications of rare earth elements in surface sediments from bays along Guangdong Coast, Southeast China. Environmental Earth Science, 65: 2195-2205.

Yang, S.Y., Hoi, S.J., Choi, S.M., Li, C.X., 2002. The rare earth element compositions of the Changjiang (Yangtze) and Huanghe
(Yellow) river sediments. Earth and Planetary Science Letters, 201: 407-419.

Yang, S., Li, C., Lee, C.B., Na, T.K., 2003. REE geochemistry of suspended sediments from the rivers around the Yellow Sea and provenance indicators. Chinese Science Bulletin, 48: 1135-1139.

Zglinicki, K., 2016. The geological-mineralogical characteristic of the contemporary coastal marine sediments of Jayapura Regency (Indonesian part of New Guinea). Ph.D. thessis (in Polish), Archive of Institute of Geochemistry, Mineralogy and Petrology, Faculty of Geology, Warsaw University.

Zwierzycki, J., 1921. Verslag over geologisch-mijnbouwkundige onderzoekingen in een gedeelte van Noord-Nieuw-Guinea. Jaarboek Mijnwezen Nederlandsch Oost-Indië. Verhandelingen, 50: 95-132. 